\title{
EFFECTS OF DIFFERENT DIETARY PROTEIN AND LYSINE LEVELS ON PERFORMANCE OF FORTY WEEKS DANDARAWI LAYING HENS AFTER PEAK PERIOD
}

\author{
M. A. Metwally
}

Department of Animal and Poultry Production, Faculty of Agriculture, Assiut University, Assiut, Egypt

\section{SUMMARY}

Two-hundred and forty local Dandarawi hens (40 wks of age) were used to investigate the effects of different levels of protein and lysine on the performance after peak period. Six experimental diets were tested in a $2 \times 3$ factorial arrangement. Two basal diets (13 and $14 \%$ protein) were tested at different levels of lysine $(20 \%$ lower than NRC, NRC and 20\% above NRC recommendations). Dietary lysine levels were $0.52,0.64$ and $0.77 \%$. During four months experimental period, body weight changes, egg production, egg weight, egg quality traits, feed intake and feed conversion and protein and lysine intake were determined.

The results indicated that $0.77 \%$ lysine (20\% above NRC recommendations) with $13 \%$ dietary protein gave significantly $(P<0.05)$ higher egg production, egg mass and better feed conversion, but there was no significant difference on egg weight. The difference in performance with different levels of lysine was lower in the 14\% dietary protein than that in the $13 \%$ dietary protein treatment. The lowest level $(0.52 \%)$ of lysine in the $14 \%$ dietary protein, led to significantly $(P<0.05)$ lower egg production and egg mass and reduced feed conversion. The best performance with $14 \%$ dietary protein belonged to $0.77 \%$ dietary lysine $(20 \%$ above NRC recommendation). The obtained results revealed that $13 \%$ dietary protein with $0.77 \%$ dietary lysine was similar to $14 \% \%$ dietary protein with $0.77 \%$ dietary lysine in egg numbers, egg production, egg mass and feed conversion. There was no significant difference on egg weight and egg quality traits except yolk percentage. It could be concluded that reducing dietary protein from 14 to $13 \%$ with $0.77 \%$ lysine of forty weeks Dandarawi laying hens gave equal performance to the higher dietary protein, thus reducing production costs.

Keywords: Protein, lysine, performance, laying hens

\section{INTRODUCTION}

The efficiency of protein utilization depends to a large extent on the amino acid composition of the diet matches the hen's requirement, the more efficient the protein of the diet is utilized. Lysine is the second limiting amino acid in corn-soybean meal diets for laying hens after methionine (Harms and Ivey 1993). Therefore, the efficiency of protein utilization is increased by supplementation of lysine (Van Weerden and Schutte, 1980; Uzu and Larbier, 1985).

Dietary protein concentration affects the requirement of the essential amino acids in laying hens. This has been demonstrated for lysine (Morris et al., 1987). Depending on the range of protein levels used and the amino acids involved, the 
requirement has been reported as increasing in direct proportion to the concentration of dietary protein but at a slower rate than the rise in dietary protein. Calderon and Jensen (1990) reported that decreasing crude protein level from 16 to $13 \%$ resulted in a significant decrease in egg production, egg weight, feed intake, feed efficiency, egg mass and body weight. Also, amino acid deficiency rather than protein per se may have been responsible for the lower egg production and egg weight (Sohail and Roland, 1997). On the other hand, Nieb (1993) concluded that crude protein of laying hen diets could be lowered by $2 \%$ without any loss in hens performance, and by $3 \%$ with only a small decrease in hens performance. Penz and Jensen (1991) found that egg weight reduction could be eliminated by supplementing low protein diets $(13 \%$ crude protein) with lysine. Also, they suggested that supplementation of lysine was able to restore daily feed consumption, yolk and shell percentages to their equivalent in the higher protein diet. Degussa (1995) researchers fed low protein diet $(13.5 \%)$ supplemented with lysine for laying hens. They found that feed intake and egg mass were constant throughout the laying period with a slight reduction in feed conversion .

National Research Council (NRC, 1994) indicates a daily methionine plus cystine requirement of $580 \mathrm{mg} / \mathrm{hen}$ and of $690 \mathrm{mg} / \mathrm{hen}$ for lysine for the White-Egg layer consuming approximately $100 \mathrm{~g}$ feed/hen/day. These recommended values suggest a ratio of 0.84 between (methionine plus cystine) and lysine. Based on the NRC recommended values of (methionine plus cystine) and lysine for the laying hens, many diets were formulated based on lysine to contain a cystine+methionine)/lysine ratio of 0.83 . Previous studies have indicated that hens fed diets formulated based on protein using a (methionine + cystine)/lysine ratio of 0.68 produced more and heavier eggs than hens fed diets formulated based on lysine using a (methionine plus cystine)/lysine ratio of 0.83 (Roland et al., 1995). Although the amount of methionine was similar in diets from the two formulation methods, more and heavier eggs were produced by hens fed diets formulated based on protein, however, hens fed diets formulated based on lysine produced more profits (Roland et al., 1995 and Sohail and Roland, 1997). It is possible that amino acid deficiency rather than protein per se may have been responsible for the lower egg production and egg weight (Sohail and Roland, 1997). Therefore, hens fed diets formulated based on lysine having methionine levels similar to diets formulated based on protein were unable to produce eggs similar in weight and number to hens fed diets formulated based on protein.

The objective of the present study was to determine if increasing dietary lysine level in a corn-soybean meal diet low in crude protein of late stage of laying could improve egg production, quality and egg components of forty weeks Dandarawi laying hens.

\section{MATERIALS AND METHODS}

A $2 \times 3$ factorial arrangement was conducted using 240 local Dandarawi laying hens (40 wks of age). Birds were randomly and equally divided into 6 groups (40 birds each) of four replicates (10 birds each) nearly similar in live body weight. Hens were housed in individual wire cages and were given feed and water ad libitum. All birds were subjected to a photoperiod of $16 \mathrm{~h}$ light. The NRC recommendation for lysine is $0.64 \%$. Two basal diets ( 13 and $14 \%$ crude protein) were tested (Table 1 ) at different levels of dietary lysine $(20 \%$ lower than NRC, NRC and $20 \%$ above 
NRC recommendations). Dietary lysine levels were $0.52,0.64$ and $0.77 \%$. The experimental diets were formulated to meet the nutrient requirements recommendations of the laying hens (NRC, 1994). Lysine was added as a commercial Lysine- $\mathrm{HCl}$ with a $98.5 \%$ activity as reported by manufacturer. The feeding trial continued for four months. Individual body weights were recorded at the beginning and at the end of the experiment to calculate body weight changes. During the experimental period, eggs were collected and recorded daily. Mortality was recorded daily. Egg laying rate were calculated for four months (120 days). Feed consumption was determined weekly and feed conversion was calculated ( $\mathrm{kg}$ feed $/ \mathrm{kg}$ eggs). Egg quality measurements were determined monthly on eggs of the last four days. Yolk index \% (Well, 1968) was calculated as yolk height divided by yolk diameter. Specific gravity of eggs was determined using the saline flotation method of Hempe et al. (1988). Salt solutions were made in incremental concentrations of 0.005 in the range from 1.060 to 1.130 . Shell thickness was determined at three locations on the egg (air cell, equator, and sharp end) using a dial pipe gauge.

Table 1. Composition and calculated analysis of the experimental diets

\begin{tabular}{|c|c|c|c|c|c|c|}
\hline \multirow[t]{3}{*}{ Ingredients, \% } & \multicolumn{3}{|c|}{$\begin{array}{l}14 \% \text { crude protein } \\
\text { (Control) }\end{array}$} & \multicolumn{3}{|c|}{$13 \%$ crude protein } \\
\hline & \multicolumn{3}{|c|}{ Lysine \% } & \multicolumn{3}{|c|}{ Lysine \% } \\
\hline & 0.52 & 0.64 & 0.77 & 0.52 & 0.64 & 0.77 \\
\hline Ground yellow corn & 65.13 & 65.13 & 65.13 & 67.63 & 67.63 & 67.63 \\
\hline Soybean meal, $44 \% \mathrm{CP}$ & 15.50 & 15.60 & 15.45 & 12.60 & 12.40 & 12.00 \\
\hline Wheat bran & 8.50 & 9.00 & 9.00 & 9.50 & 9.50 & 9.50 \\
\hline Limestone & 7.55 & 7.55 & 7.55 & 7.55 & 7.55 & 7.55 \\
\hline Dicalcium phosphate & 2.00 & 2.00 & 2.00 & 2.00 & 2.00 & 2.00 \\
\hline Salt & 0.30 & 0.30 & 0.30 & 0.30 & 0.30 & 0.30 \\
\hline Vit.\&Min. Mix.* & 0.30 & 0.30 & 0.30 & 0.30 & 0.30 & 0.30 \\
\hline DL-Methionine & 0.12 & 0.12 & 0.12 & 0.12 & 0.12 & 0.12 \\
\hline Lysine-HCl & 0.00 & 0.00 & 0.15 & 0.00 & 0.10 & 0.25 \\
\hline Sand & 0.60 & 0.00 & 0.00 & 0.00 & 0.10 & 0.35 \\
\hline Total & 100 & 100 & 100 & 100 & 100 & 100 \\
\hline \multicolumn{7}{|l|}{ Calculated analysis } \\
\hline $\mathrm{ME}, \mathrm{Kcal} / \mathrm{kg}$ & 2651 & 2658 & 2662 & 2680 & 2681 & 2677 \\
\hline $\mathrm{CP}, \%$ & 14.00 & 14.00 & 14.00 & 13.00 & 13.00 & 13.00 \\
\hline Fat, $\%$ & 2.96 & 2.97 & 2.94 & 3.00 & 2.98 & 2.98 \\
\hline Fiber, $\%$ & 3.12 & 3.47 & 3.44 & 3.40 & 3.00 & 3.00 \\
\hline $\mathrm{Ca}, \%$ & 3.36 & 3.37 & 3.36 & 3.36 & 3.35 & 3.35 \\
\hline $\mathrm{P}, \%$ (available) & 0.48 & 0.50 & 0.50 & 0.50 & 0.48 & 0.48 \\
\hline Lys, $\%$ & 0.52 & 0.64 & 0.77 & 0.52 & 0.64 & 0.77 \\
\hline Met + cys,$\%$ & 0.66 & 0.61 & 0.64 & 0.59 & 0.60 & 0.61 \\
\hline \multicolumn{7}{|l|}{ Analyzed values } \\
\hline $\mathrm{CP}, \%$ & 13.96 & 14.05 & 13.95 & 13.05 & 13.08 & 12.94 \\
\hline Lys, $\%$ & 0.50 & 0.61 & 0.77 & 0.51 & 0.67 & 0.75 \\
\hline
\end{tabular}


For albumen and yolk solids and crude protein determinations, twelve eggs for each group were taken. Yolk and albumen were separated manually. Adhering albumen and chalazae were removed from the yolk with a metal spatula on a glass separating table. Weight of yolk and wet shell with shell membranes intact were subtracted from the whole egg weight to calculate albumen weight for each individual egg as described by Fletcher et al., (1981). Albumen and yolk components were kept separate but pooled by dietary group and stored at $5{ }^{\circ} \mathrm{C}$. The pooled samples were removed the next day and homogenized using a commercial blender prior to further analysis. Total solids were determined for albumen and yolk gravimetrically by oven drying. Samples of approximately $10 \mathrm{~g}$ were dried for $24 \mathrm{~h}$ at $105^{\circ} \mathrm{C}$ in an oven (AOAC, 1984). Two sub-samples for each sample by dietary groups of yolk and albumen homogenates were analyzed for total nitrogen by standard kjeldahl procedure (AOAC, 1984). Protein values were calculated by multiplying nitrogen values by 6.25 .

\section{Economic evaluation:}

Economical efficiency was estimated relative to unsupplemented control group as follows:

$$
\text { Relative feeding cost }=\frac{\text { Supplemented group feeding cost }}{\text { unsupplemented control group feeding cost }}
$$

\section{Statistical analysis:}

The data were analyzed using the General Linear Models (GLM) procedure of SAS (SAS Institute, 1990). Difference among means within the same factor were tested for significance using Duncan's new multiple range test (Duncan 1955).

\section{RESULTS AND DISCUSSION}

\section{Body weight and body weight changes:}

Results on the effect of different levels of protein and lysine on body weight and body weight changes of Dandarawi laying hens are presented in Table 2. The results indicated that protein level had no significant effect $(\mathrm{P}<0.05)$ on body weight or body weight changes. Lysine level had significant effect $(\mathrm{P}<0.05)$ on body weight and body weight changes. Birds received the highest level of lysine $(0.77 \%)$ had the highest body weight changes $(12.52 \%)$ compared to control birds $(10.07 \%)$ that received the recommended level of lysine (0.64\%) of NRC (1994). There were significant interactions between lysine and protein levels on body weight changes. Birds received low protein level (13\%) and the highest level of lysine $(0.77 \%)$ gave a reasonable final body weight and the best body weight changes. The positive response in body weight changes due to lysine supplementation are in agreement with the findings of Novak et al., (2004). 
Table 2. Effects of protein and lysine levels on body weight changes

\begin{tabular}{|c|c|c|c|}
\hline \multirow[b]{2}{*}{ S.O.V } & \multicolumn{3}{|c|}{ Body weight } \\
\hline & Initial (g) & Final (g) & Changes, $\%$ \\
\hline \multicolumn{4}{|c|}{ Protein $(\mathrm{P}) \%$} \\
\hline 13 & 1177 & 1315 & 10.49 \\
\hline 14 & 1200 & 1343 & 10.64 \\
\hline \multicolumn{4}{|c|}{ Lysine (L), \% } \\
\hline 0.52 & 1201 & $1319^{b}$ & $8.95^{\mathrm{c}}$ \\
\hline 0.64 & 1178 & $1310^{b}$ & $10.07^{b}$ \\
\hline 0.77 & 1187 & $1357^{\mathrm{a}}$ & $12.52^{\mathrm{a}}$ \\
\hline \multicolumn{4}{|l|}{ PX L } \\
\hline $13 \times 0.52$ & 1197 & $1307^{\mathrm{c}}$ & $8.42^{\mathrm{b}}$ \\
\hline $13 \times 0.64$ & 1210 & $1367^{\mathrm{a}}$ & $11.48^{\mathrm{ab}}$ \\
\hline $13 \times 0.77$ & 1164 & $1346^{\mathrm{a}}$ & $13.52^{\mathrm{a}}$ \\
\hline $14 \times 0.52$ & 1171 & $1289^{d}$ & $9.15^{b}$ \\
\hline $14 \times 0.64$ & 1185 & $1331^{\mathrm{b}}$ & $10.97^{\mathrm{ab}}$ \\
\hline $14 \times 0.77$ & 1206 & $1330^{\mathrm{b}}$ & $9.32^{b}$ \\
\hline \multicolumn{4}{|l|}{ Probability } \\
\hline $\mathrm{P}$ & NS & NS & NS \\
\hline $\mathrm{L}$ & NS & $*$ & $*$ \\
\hline PX L & NS & * & $*$ \\
\hline
\end{tabular}

\section{Feed intake and feed conversion ratio:}

Feed intake and feed conversion data (Table 3) showed that the effect of protein or lysine was not significant for feed intake values. The obtained results are in agreement with that reported by Prochaska et al. (1996). On the other hand, protein and lysine levels had significant effects $(\mathrm{P}<0.05)$ on feed conversion. However, birds fed the low protein diets $(13 \%)$ had the worst feed conversion values than those fed the control diets (14\% protein). Similar findings were reported by Calderon and Jensen (1990). They found that decreasing crude protein levels from 16 to $13 \%$ resulted in a significant decrease in feed conversion. On the other hand, Nieb (1993) concluded that crude protein of laying hen diets could be lowered by $2 \%$ without any loss in hen performance, and by $3 \%$ with only a small decrease in hens performance. For lysine effects, feed conversion was significantly $(\mathrm{P}<0.05)$ better as layer diets were supplemented with lysine. Birds fed the highest level of lysine $(0.77 \%)$ had the best feed conversion values compared to those fed the lowest level $(0.52 \%)$ or those fed the NRC recommended levels of lysine $(0.64 \%)$. The obtained results are in agreement with those reported by Novak et al., (2004). Feed conversion increased with increasing lysine levels from 0.7 to $0.8 \%$ in a sunflower seed basal diet (Karunajeewa et al., 1987). Also, there were significant interactions between lysine and protein levels on feed intake and feed conversion. Birds fed the highest level of lysine $(0.77 \%)$ with low level of protein $(13 \%)$ had similar feed intake and feed conversion values with those fed the highest level of lysine $(0.77 \%)$ and $14 \%$ protein. The obtained results are in agreement with those reported by Degussa (1995) researchers. They found that laying hens fed low protein diet $(13.5 \%)$ supplemented 
with lysine had constant feed intake throughout the laying period with a slight reduction in feed conversion.

\section{Mortality rate:}

Only three hens died during the four month laying period. Results revealed that mortality rate was not related to dietary treatments, subsequently data were not shown.

\section{Egg production traits:}

Effects of different levels of protein and lysine on egg production traits of Dandarawi laying hens are presented in Table 3. Egg weight was not significantly $(\mathrm{P}<0.05)$ affected by the main effects of protein, lysine or by the interactions. Egg number, egg mass and laying rate values were significantly $(\mathrm{P}<0.05)$ affected by level of protein and lysine. Egg number, egg mass and laying rate were significantly $(\mathrm{P}<0.055)$ increased by the highest levels of dietary protein or lysine. Calderon and Jensen (1990) found that decreasing crude protein levels from 16 to $13 \%$ resulted in a significant decrease in egg production and egg mass. Sohail and Roland (1997) found that amino acid deficiency rather than protein may have been responsible for lower egg production. Egg mass increased when lysine levels increased from 0.7 to $0.8 \%$ in a sunflower seed basal diet (Karunajeewa et al., 1987). Also, There were significant interactions between lysine and protein levels on egg number, egg mass and laying rate values. In general, greater improvements $(60.13 \%$ for egg laying rate, 18.04 for egg number and $758.4 \mathrm{~g}$ for egg mass) were obtained with the highest levels of lysine $(0.77 \%)$ with low protein $(13 \%)$ compared to the lowest level of lysine or NRC recommended level of lysine $(0.64 \%)$ with control level of protein $(14 \%)$. Also, Birds fed the highest level of lysine $(0.77 \%)$ with low level of protein $(13 \%)$ had similar values of laying rate and egg number with protein $(14 \%)$ and $0.77 \%$ lysine. The obtained results are in agreement with that reported by Degussa (1995) researchers. They found that laying hens fed low protein diet $(13.5 \%)$ supplemented with lysine had constant egg mass throughout the laying period.

\section{Egg quality traits:}

Effects of dietary protein and lysine levels on egg quality traits are presented in Table 4. There were no significant effects of dietary protein or lysine supplementation or the interactions between protein and lysine levels on egg quality traits (egg weight, albumen \%, shell \%, yolk index \%, shell thickness (mm) and specific gravity) except yolk percentage. The highest level of lysine $(0.77 \%)$ led to higher percentage of egg yolk percentage. Birds fed $0.77 \%$ lysine had egg yolk $33.75 \%$ compared to $32.05 \%$ for those fed the lower level of lysine $(0.52 \%)$. Birds received $13 \%$ protein and $0.77 \%$ lysine diet had egg yolk \% (35.28\%) nearly similar $(34.13 \%)$ to those fed $14 \%$ protein and $0.77 \%$ lysine. Similar findings were reported by El-Boushy et al., (1980). They found that egg weight and egg quality as indicated by proportions of shell and albumen were not affected by the increasing levels of protein from $12 \%$ to $16 \%$ crude protein with diets supplemented with lysine and methionine. Bertram et al., $(1989,1995)$ and Schutte et al. (1994) found that low protein diets can be fed without loss in the production performance. 


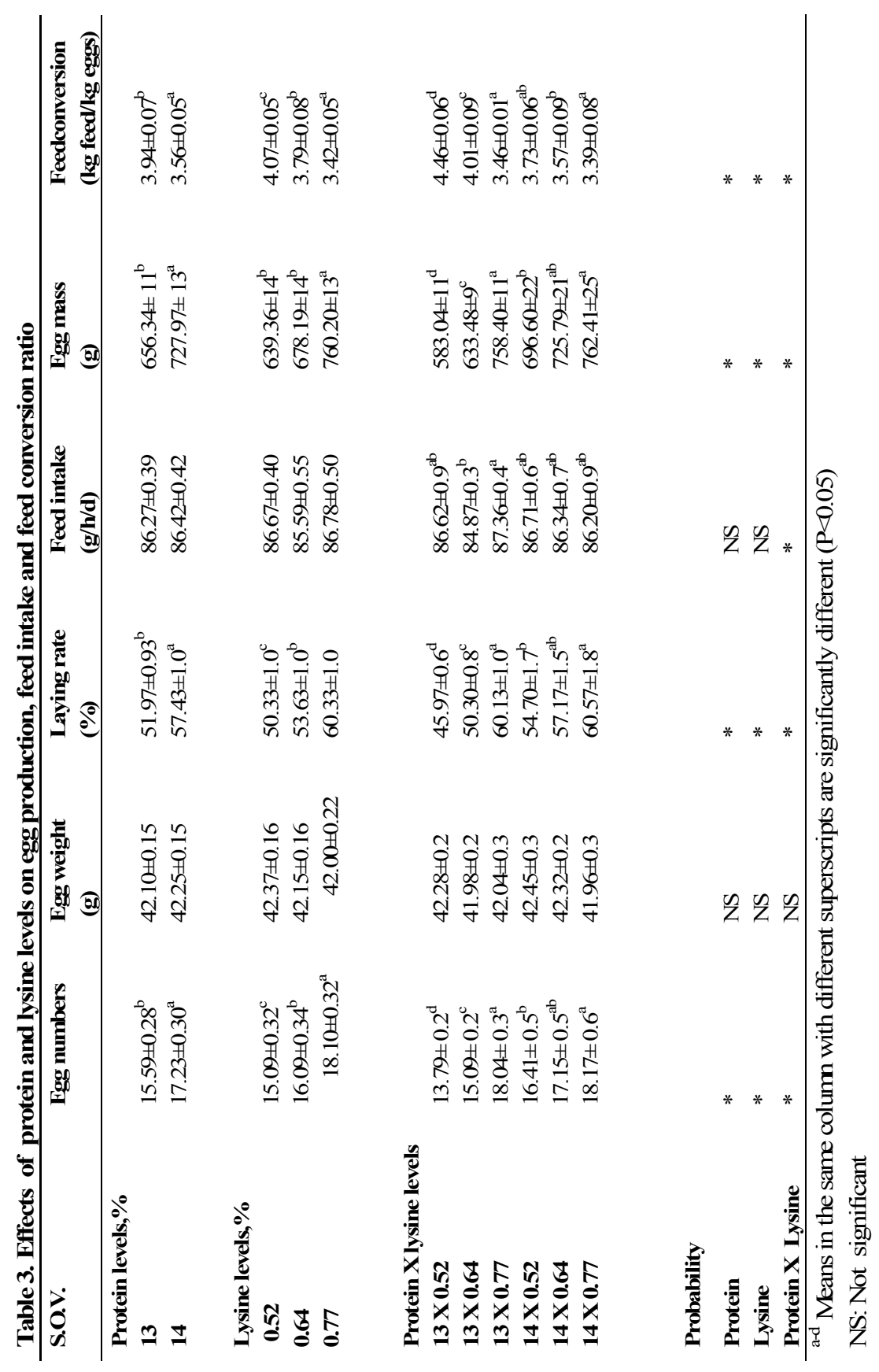




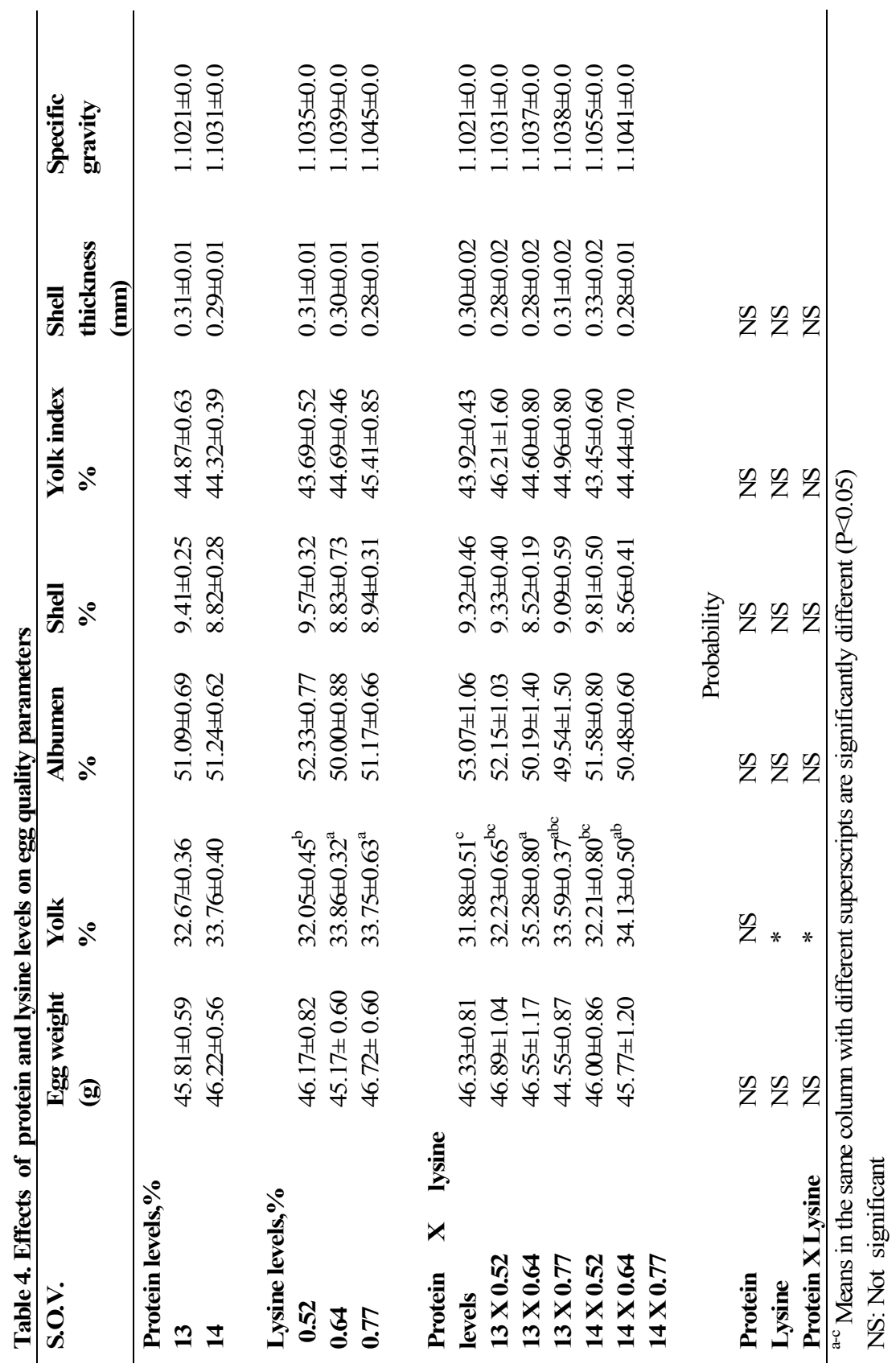


6. Egg component total solids and egg crude protein content:

The results of the effects of dietary protein and lysine levels on egg component yield total solids and crude protein content in eggs are presented in Table 5. It was observed that protein and lysine levels and the interactions between protein and lysine levels had significant effects on albumen solids and protein. Lysine level of $0.77 \%$ compared to 0.52 or $0.64 \%$ significantly increased albumen solids and protein. Birds fed the higher levels of lysine had significantly increased albumen solids and protein. The obtained results are in agreement with that reported by Prochaska et al., (1996) and Novak et al. (2004). Averages of albumen solids were 11.47, 11.24 and $11.37 \%$ for $0.77,0.52$ and $0.64 \%$ of lysine levels, respectively. The highest level of lysine $(0.77 \%)$ with $13 \%$ protein had the highest values of both albumen solids and albumen protein. Similar trend was observed with Dandarawi laying hens fed $0.77 \%$ of lysine and $14 \%$ protein. One plausible mechanism for increasing of protein levels in albumen involves the pancreatic hormone system and insulin. Two of insulin's activities include increasing amino acid uptake and protein synthesis (Sturkie, 1986). Increasing dietary amino acids, such as lysine to elevated levels may induce their increased incorporation into the plasma. This increased incorporation promotes insulin release by the pancrease and the subsequent uptake of amino acids and protein synthesis. In support, it has been shown that insulin has direct effects on the specific mRNA synthesis mechanisms of avalbumin (Murray et al., 1988).

Table 5. Effects of protein and lysine levels on egg component total solids and crude protein content in eggs

\begin{tabular}{|c|c|c|c|c|}
\hline \multirow[b]{2}{*}{ S.O.V } & \multicolumn{4}{|c|}{$\%$} \\
\hline & Albumen solids & Albumen protein & Yolk solids & Yolk protein \\
\hline \multicolumn{5}{|l|}{ Protein $(\mathrm{P})$} \\
\hline$\%$ & $11.69^{\mathrm{a}}$ & $10.31^{\mathrm{b}}$ & 52.11 & 15.65 \\
\hline 13 & $11.24^{\mathrm{b}}$ & $10.56^{\mathrm{a}}$ & 51.97 & 15.01 \\
\hline \multicolumn{5}{|l|}{14} \\
\hline \multicolumn{5}{|l|}{ Lysine (L), } \\
\hline$\%$ & $11.24^{\mathrm{c}}$ & $10.42^{\mathrm{c}}$ & 52.38 & $15.69^{\mathrm{ab}}$ \\
\hline 0.52 & $11.37^{\mathrm{b}}$ & $10.46^{\mathrm{b}}$ & 52.32 & $15.54^{\mathrm{b}}$ \\
\hline 0.64 & $11.47^{\mathrm{a}}$ & $10.66^{\mathrm{a}}$ & 52.30 & $15.79^{\mathrm{a}}$ \\
\hline \multicolumn{5}{|l|}{0.77} \\
\hline \multicolumn{5}{|l|}{ P X L } \\
\hline $13 \times 0.52$ & $11.64^{\mathrm{b}}$ & $10.43^{\mathrm{c}}$ & 52.64 & $15.49^{\mathrm{b}}$ \\
\hline $13 \times 0.64$ & $11.57^{\mathrm{c}}$ & $10.50^{\mathrm{b}}$ & 52.01 & $15.53^{\mathrm{ab}}$ \\
\hline $13 \times 0.77$ & $11.78^{\mathrm{a}}$ & $10.71^{\mathrm{a}}$ & 51.83 & $15.67^{\mathrm{a}}$ \\
\hline $14 \times 0.52$ & $11.46^{\mathrm{d}}$ & $10.52^{\mathrm{b}}$ & 51.56 & $15.33^{\mathrm{c}}$ \\
\hline $14 \times 0.64$ & $11.34^{\mathrm{e}}$ & $10.41^{\mathrm{c}}$ & 51.45 & $15.51^{\mathrm{ab}}$ \\
\hline $14 \times 0.77$ & $11.75^{\mathrm{a}}$ & $10.68^{\mathrm{a}}$ & 51.40 & $15.70^{\mathrm{a}}$ \\
\hline \multicolumn{5}{|c|}{ Probability } \\
\hline $\mathbf{P}$ & $*$ & $*$ & NS & NS \\
\hline $\mathbf{L}$ & $*$ & $*$ & NS & $*$ \\
\hline $\mathbf{P} \times \mathbf{L}$ & $*$ & $*$ & NS & $*$ \\
\hline
\end{tabular}


There was no significant effects $(\mathrm{P}<0.05)$ of protein, lysine levels and the interactions on yolk solids \%. The obtained results concerned with lysine levels had not significant effect on yolk solids \% are in agreement with that reported by Prochaska et al., (1996). Protein levels had not significant effects on yolk protein. Lysine levels and the interactions has positive significant effects on yolk protein. Increased levels of lysine significantly increased yolk protein. Averages of yolk protein were $15.79,15.69$ and $15.54 \%$ for $0.77,0.52$ and $0.64 \%$ of lysine levels, respectively. Birds fed diets containing the highest level of lysine $(0.77 \%)$ and $13 \%$ crude protein had similar trends in yolk protein \% with those fed diets containing $0.77 \%$ of lysine and $14 \%$ crude protein.

\section{Economic evaluation:}

Results of economic evaluation for using different levels of protein and lysine are presented in Table 6 . The obtained results showed that the highest level of lysine $(0.77 \%)$ with low protein level $(13 \%)$ had a lowest value in the total feeding cost compared to any other levels of lysine and protein.

Because commercial poultry operations are interested mainly in the economic returns, it is evident that using $0.77 \%$ lysine ( $20 \%$ above NRC recommended level) with low protein levels (13\%) during the post peak period (the late period of laying) of Dandarawi laying hens achieved good performance and economic returns similar to higher levels of protein $(14 \%)$ and lysine $(0.77 \%)$, thus reducing production costs.

Table 6. Economic evaluation for using different levels of protein and lysine in forty weeks Dandarawi laying hen diets during the laying period (120 days).

\begin{tabular}{|c|c|c|c|c|c|c|}
\hline \multirow[b]{3}{*}{ Item } & \multicolumn{3}{|c|}{$14 \%$ crude protein } & \multicolumn{3}{|c|}{$13 \%$ crude protein } \\
\hline & \multicolumn{3}{|c|}{ Lysine levels (\%) } & \multicolumn{3}{|c|}{ Lysine levels (\%) } \\
\hline & 0.64 & 0.52 & 0.77 & 0.64 & 0.52 & $\mathbf{0 . 7 7}$ \\
\hline Egg No./hen & 68.6 & 65.54 & 72.17 & 60.36 & 55.16 & 72.16 \\
\hline Feed/egg ${ }^{1}$ & 151.7 & 158.8 & 143.3 & 168.7 & 188.44 & 146.1 \\
\hline Total feeding & 17.61 & 16.84 & 17.66 & 15.27 & 14.75 & 15.30 \\
\hline $\operatorname{cost}^{2}$ & 0.256 & 0.257 & 0.245 & 0.252 & 0.267 & 0.212 \\
\hline Feeding cost/egg & & & & & & \\
\hline Cost/egg & 100 & 100 & 95.70 & 98.43 & 104.2 & 0.82 \\
\hline
\end{tabular}




\section{REFERENCES}

A.O.A.C., 1984. Official Methods of Analysis. $14^{\text {th }}$ ed. Association of Official Analytical Chemists, Washington,D.C.

Bertram, H.L., E. Danner, K.Jeroch and H. Jeroch, 1995. Effect of DL-methionine in a cereal-pea diet on the performance of brown laying hens. Arch. Geflugelk, 59, 1:103-107.

Bertram, H.L., J.B. Schutte and E.J. Van Weerden, 1989. Methionine and sulfur amino acid requirements for laying hens in a low protein diet. Procd. $7^{\text {th }}$ Europ. Symosium on Poultry Nutrition, June 19-21, Lloret de Mar, Spain.

Calderon, V.M, and L.S. Jensen, 1990. The requirements for sulfur amino acid by laying hens as influenced by protein concentration. Poultry. Sci. 69: 934-944.

Degussa, 1995. Reducing the protein content of layer diets. Degussa feed back special IC-FA-AT/Feedb. Sp-5e. Be/11.95. Anonymous, 1994. Amino acid requirements of fowl (poultry) in relation to total nitrogen utilization. De Molnaar, 97 (4): 45-46.

Duncan, D.B. 1955. Multiple range and F tests.Biometrics 11: 1-42.

El-Boushy, A.R., L.G.M. Van Gills and M.C. Papadopoulos, 1980. Effect of protein and energy levels in a constant ratio supplemented with methionine and lysine on performance of layers and on egg quality. Neth. J. Agric. Sci. 28: 29-35.

Fletcher, D.L., W.M.Britton, A.P. Rahn and S.I. Savage, 1981. The influence of layer flock age on egg component yields and solids content. Poultry. Sci. 60:983-987.

Harms, R. H. and F.J. Ivey, 1993. Performance of commercial laying hens fed various supplemental amino acids in a corn-soybean meal diet. J. Appl. Poult.Res., 2:273-282.

Hempe, J.M., R.C. Lauxen and J.E. Savage, 1988. Rapid determination of egg weight and specific gravity using a computerized data collection system. Poultry. Sci., 67:902-907.

Karunajeewa, H., S.Abu-Serewa, S, S.H. Tham and P. Eason, 1987. The effects of level of sunflower seeds and lysine on egg quality and laying performance of White Leghorn hens. J. Sci. Food Agric. 41: 325-333.

Morris, T.R., K. Al-Azzawi, R.M. Gous and G.L. Simpon, 1987. Effects of protein concentration on responses to dietary lysine by chicks. Br. Poult. Sci. 28: 185195.

Murray, R.K., D.K. Kranner, P.A. Mayes and V.W. Rodwell, 1988. Harpers Biochemistry. Appleton and Lange, Norwalk, CT.

National Research Council, 1994. Nutrient Requirement of Poultry. $9^{\text {th }}$ rev. ed. National Academy Press, Washington. DC.

Nieb, E., 1993. Reduction of $\mathrm{N}$ excretion by supplementing poultry diets with crystalline amino acids. Arch. Geflugelk, 57, 3:103-107.

Novak, C., H.Yakout and S. Scheideler, 2004. The combined effects of dietary lysine and total sulfur amino acid level on egg production parameters and egg components in Dekalb Delta laying hens. Poultry. Sci. 83:977-984.

Penz, A.M. and L.S. Jensen, 1991. Influence of protein concentration, amino acids supplementation and daily access to high or low-protein diets on egg weight and components in laying hens. Poultry Sci., 70: 2460-2466.

Prochaska, J.F., J.B. Carey and D.J. Shafer, 1996. The effect of L-lysine intake on egg component yield and composition in laying hens. Poultry Sci., 75:1268-1277. 
Roland, D.A., Sr., M.M. Bryant and J. Self, 1995. Econometric feeding: Performance and profits of commercial Leghorns (Phase 1) fed diets formulated based on protein versus lysine. Poultry Sci., 74 (Suppl. 1): 66

SAS, 1990. SAS User's Guide: Statistics. SAS Institute, Inc., Cary, NC, USA.

Schutte, J.B., D.E. Jong and H.L. Bertram, 1994. Requirement of laying hens fed sulfur amino acids. Poultry Sci., 73: 274-280.

Sohail, S.S. and D. A. Roland, SR., 1997. Partial explanation for difference in response of hens fed diets formulated based on protein vs lysine. Poultry.Sci., 76 (Suppl. 1): 107

Sturkie, P.D., 1986. Avian Physiology. Springer-Verlag, New York, Inc., NY.

Uzu, G. and M. Larbier, 1985. Lysine requirement in laying hens. Arch. Geflugekd, 49:148-150.

Van Weerden, E.J. and J.B. Schutte, 1980. Lysine requirement of the laying hen. Arch.Geflugekd.44:36-40.

Well, R. J., 1968. The Measurement of Certain Egg Quality: A Study of the Hens Egg. Ed. By T.C. Carter Pub. Oliver and Boy, Edinbrugh, UK pp. 220-226 and 235-236. 
تأثير المستويات المختلفة من البروتين والليسين المأكول على معدل أداء دجاجات الانداراوى البياضة عمر ·ـ أسبوع في الفترة بعد قمة الإنتاج

محمد متولى أحمد حامد

قسم الإنتاج الحيوانى، كلية النزاعة، جامعة أسيوط، مصر

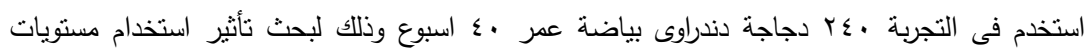

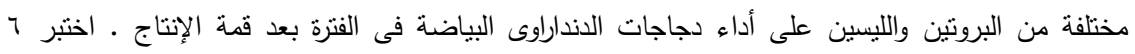

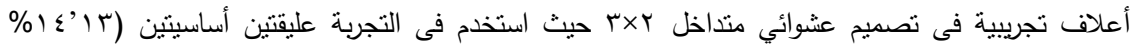

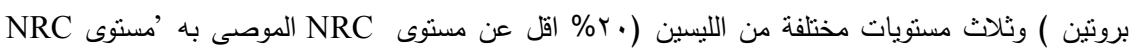

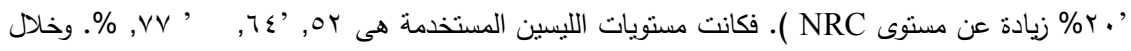

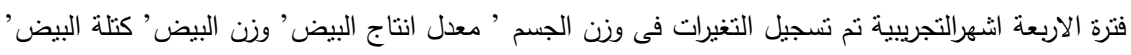

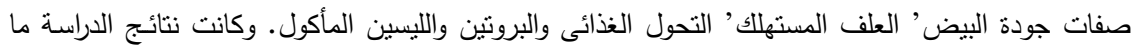
يلى:

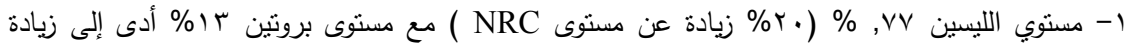

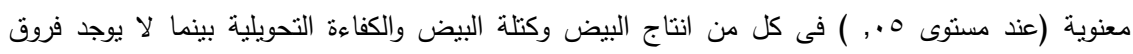

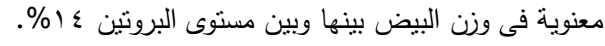

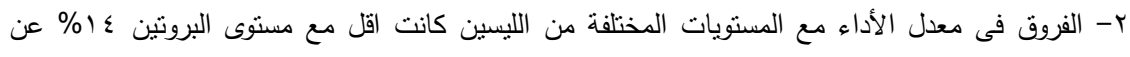

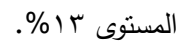

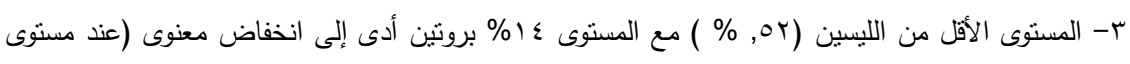
ه. . ) ) فى كل من انتاج البيض وكنلة البيض وكذاللك الكفاءة التحويلية.

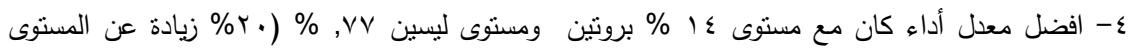
.$(\mathrm{NRC}$

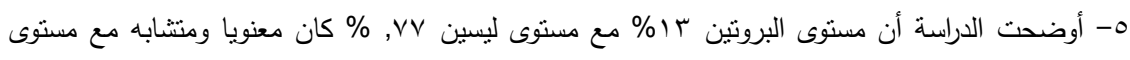

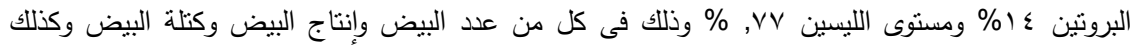
الكفاءة التحويلية وكذلك صفات جودة الييض عدا النسبة المئوية للصفار .

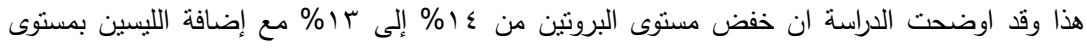

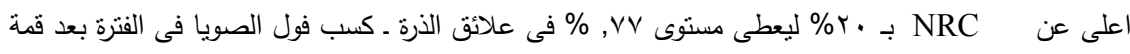

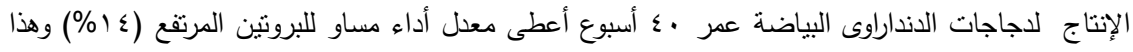

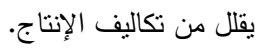

